Ramiz M. Aliguliyev ${ }^{1}$, Gunay Y. Niftaliyeva ${ }^{2}$

DOI: 10.25045/jpit.v08.i1.07

Institute of Information Technology of ANAS, Baku, Azerbaijan

${ }^{1}$ r.aliguliyev@gmail.com; ${ }^{2}$ gunay90@ hotmail.com

\title{
THE CURRENT STATE, PROBLEMS AND PERSPECTIVES OF E-GOVERNMENT ANALYSIS TECHNOLOGIES
}

In this paper, e-government maturity models have been analyzed. The role of text mining and social network analysis technologies in e-government was investigated; the current state of research in this field has been analyzed. In the result of investigation, the existing problems and future research directions in this field have been identified.

Keywords: e-government, e-government models, text mining, social network analysis.

\section{Introduction}

Our century is an age of information and high technologies. Advanced technology products have become an integral part of our lives. Today, the progress of Information Technology (IT) is one of the main factors that affect the efficiency, performance and working principles of various organizations, companies, government agencies. The involvement of IT in the management processes of the society has resulted with the formation of e-government concept [1]. Egovernment implies increasing of efficiency of government agencies and facilitating of citizens' access to e-services with the wide application of information and communication technologies. The key purpose of e-government is the facilitation of services delivered to the citizens, the improvement of the relations of businesses and industrial facilities, more efficient governing and less corruption and the increase of transparency [2,3].

The concept of e-government was first formed in mid-1990s as a result of the application of information and communication technologies in public administration agencies. Generally, it should be noted that, although the concept of e-government has formed during this period, the application of computer in management goes back to the date of the first computer [4]. Previously, the application of IT in the management implied the computerization of government agencies, whereas currently, the e-government concept means the e-services provided to the citizens by the government. Citizens' utility payments, documentation procedures, registration, and participation in the elections, petitions and requests through an electronic platform can be shown as an example of e-services.

E-government is studied through building the models of the development stages. Different models have been proposed by researchers to evaluate the development of e-government. Maturity models of e-government include a set of stages (from the simple to the complex), which define the perfection of e-government portal. The main purpose of these models is to improve the quality of egovernment portal. E-government maturity models are listed in Table 1, in a chronological order.

To improve these models e-government portal should thoroughly be analyzed, and the opinions of the citizens should be studied. It is known that, the aim of the e-government services is to increase the citizen's satisfaction, their convenience, and to provide the role of citizens in the governance. Social networks have great advantages for the study of G2C (government-to-citizen), G2B (government-to-business) and G2G (government-to-government) relations in e-government environment. By analyzing these networks, it is possible to improve the quality and to provide the security of public services. At the same time, the role of citizens in the decision making process can be provided by analyzing the citizens' wishes and proposals. 
E-government maturity models

\begin{tabular}{|c|c|c|c|c|c|c|}
\hline Model & Stage 1 & Stage 2 & Stage 3 & Stage 4 & Stage 5 & Stage 6 \\
\hline $\begin{array}{c}\text { Gartner group } \\
\text { [5], } 2000\end{array}$ & $\begin{array}{c}\text { Online } \\
\text { availability }\end{array}$ & Interaction & Transaction & Transformation & - & - \\
\hline $\begin{array}{c}\text { Deloitte } \\
\text { andTouche [6], } \\
2000\end{array}$ & $\begin{array}{l}\text { Information } \\
\text { publication }\end{array}$ & $\begin{array}{l}\text { Official bilateral } \\
\text { relation }\end{array}$ & $\begin{array}{l}\text { Multi-purpose } \\
\text { portals }\end{array}$ & $\begin{array}{c}\text { Portal } \\
\text { customization }\end{array}$ & $\begin{array}{l}\text { Integrated } \\
\text { service } \\
\text { clustering }\end{array}$ & $\begin{array}{c}\text { Complete } \\
\text { integration } \\
\text { and } \\
\text { corporate } \\
\text { agreements } \\
\end{array}$ \\
\hline $\begin{array}{l}\text { Layne and Lee } \\
\text { [7], } 2001\end{array}$ & Cataloging & Transaction & $\begin{array}{l}\text { Horizontal } \\
\text { integration }\end{array}$ & $\begin{array}{l}\text { Vertical } \\
\text { integration }\end{array}$ & - & - \\
\hline $\begin{array}{c}\text { Hiller and } \\
\text { Belanger [8], } \\
2001 \\
\end{array}$ & Information & Interaction & Transaction & Integration & Participation & - \\
\hline $\begin{array}{l}\text { Wescott [9], } \\
\quad 2001\end{array}$ & $\begin{array}{c}\text { E-mail and } \\
\text { internal network } \\
\text { system building }\end{array}$ & $\begin{array}{l}\text { Improvement of } \\
\text { information } \\
\text { access between } \\
\text { organizations } \\
\text { and society }\end{array}$ & $\begin{array}{l}\text { Building } \\
\text { bilateral } \\
\text { relations }\end{array}$ & $\begin{array}{l}\text { Knowledge } \\
\text { exchange }\end{array}$ & e-Democracy & $\begin{array}{l}\text { United } \\
\text { government }\end{array}$ \\
\hline $\begin{array}{l}\text { United Nations } \\
\& \text { ASPA [10], } \\
2002 \\
\end{array}$ & $\begin{array}{c}\text { Developing } \\
\text { information } \\
\text { services } \\
\end{array}$ & $\begin{array}{c}\text { Extended } \\
\text { information } \\
\text { services } \\
\end{array}$ & Interactive & $\begin{array}{l}\text { Transaction } \\
\text { Services }\end{array}$ & $\begin{array}{l}\text { Related } \\
\text { Services }\end{array}$ & - \\
\hline Moon [11], 2002 & $\begin{array}{c}\text { Simple } \\
\text { information } \\
\text { dissemination }\end{array}$ & Bilateral relation & $\begin{array}{l}\text { Services and } \\
\text { financial } \\
\text { transactions }\end{array}$ & Integration & $\begin{array}{l}\text { Participation } \\
\text { in political } \\
\text { life }\end{array}$ & - \\
\hline $\begin{array}{l}\text { Chandler and } \\
\text { Emanuel [12], } \\
2002 \\
\end{array}$ & Information & Interaction & Transaction & Integration & - & - \\
\hline $\begin{array}{l}\text { Windley [13], } \\
2002\end{array}$ & Simple Website & $\begin{array}{c}\text { Online } \\
\text { government }\end{array}$ & $\begin{array}{l}\text { Integrated } \\
\text { Government }\end{array}$ & $\begin{array}{l}\text { Transformed } \\
\text { Government }\end{array}$ & - & - \\
\hline $\begin{array}{l}\text { World Bank [14], } \\
2003\end{array}$ & Publication & Interaction & Transaction & - & - & - \\
\hline $\begin{array}{l}\text { Accenture [15] } \\
2003\end{array}$ & $\begin{array}{c}\text { Online } \\
\text { availability }\end{array}$ & $\begin{array}{c}\text { Key } \\
\text { opportunities }\end{array}$ & $\begin{array}{c}\text { Service } \\
\text { availability }\end{array}$ & $\begin{array}{l}\text { Advanced } \\
\text { delivery }\end{array}$ & $\begin{array}{c}\text { Service } \\
\text { transforma- } \\
\text { tion } \\
\end{array}$ & - \\
\hline $\begin{array}{l}\text { Siau and Long } \\
\text { [16], 2005 }\end{array}$ & $\begin{array}{c}\text { Online } \\
\text { availability }\end{array}$ & Interaction & Transaction & Transformation & e-Democracy & - \\
\hline $\begin{array}{l}\text { Shahkooh [17], } \\
2008\end{array}$ & $\begin{array}{c}\text { Online } \\
\text { availability }\end{array}$ & Interaction & Transaction & $\begin{array}{c}\text { Complete } \\
\text { integrated e- } \\
\text { democracy }\end{array}$ & e-Democracy & - \\
\hline $\begin{array}{c}\text { Almazan and } \\
\text { GilGarcia [18], } \\
2008 \\
\end{array}$ & Availability & Information & Interaction & Transaction & Integration & $\begin{array}{c}\text { Participa- } \\
\text { tion in } \\
\text { political life }\end{array}$ \\
\hline $\begin{array}{l}\text { Kim and Grant } \\
\text { [19], } 2010\end{array}$ & $\begin{array}{c}\text { Online } \\
\text { availability }\end{array}$ & Interaction & Transaction & Integration & $\begin{array}{l}\text { Sustainable } \\
\text { Development }\end{array}$ & - \\
\hline $\begin{array}{l}\text { Alhomod etc. } \\
\text { [20], } 2012\end{array}$ & $\begin{array}{c}\text { Online } \\
\text { availability }\end{array}$ & $\begin{array}{c}\text { Interaction } \\
\text { between citizens } \\
\text { and government }\end{array}$ & $\begin{array}{l}\text { Complete } \\
\text { transaction } \\
\text { over the } \\
\text { Internet }\end{array}$ & $\begin{array}{c}\text { Service } \\
\text { integration }\end{array}$ & - & - \\
\hline $\begin{array}{c}\text { United Nations, } \\
\text { [21], } 2012\end{array}$ & $\begin{array}{l}\text { Developing } \\
\text { information } \\
\text { services }\end{array}$ & $\begin{array}{l}\text { Extended } \\
\text { information } \\
\text { services }\end{array}$ & $\begin{array}{l}\text { Transaction } \\
\text { services }\end{array}$ & $\begin{array}{l}\text { Related } \\
\text { services }\end{array}$ & - & - \\
\hline $\begin{array}{c}\text { Lee and Kwak } \\
\text { [22], } 2012 \\
\end{array}$ & $\begin{array}{c}\text { Initial } \\
\text { conditions }\end{array}$ & $\begin{array}{l}\text { Information } \\
\text { transparency }\end{array}$ & $\begin{array}{c}\text { Open } \\
\text { participation }\end{array}$ & $\begin{array}{c}\text { Open } \\
\text { cooperation }\end{array}$ & $\begin{array}{c}\text { Participation } \\
\text { anywhere }\end{array}$ & - \\
\hline
\end{tabular}


As the citizens can express their opinions in the text form in an electronic environment, one of the most advanced technologies - namely, text mining can be used for the analysis of these opinions.

Apparently, text mining and social network analysis technologies can improve e-government system more. Considering actuality of the problems mentioned above, in this study the researches that have been done in the direction of text mining and social network analysis technologies and the role of these technologies in e-government have been reviewed and analyzed.

\section{Text mining technologies in e-government}

E-government implies better delivery of public services, the development of mutual relations between business and industrial facilities, the empowerment of citizens through access to information, and more efficient governance. In other words, e-government simplifies internal operations and improves the activities of government agencies by helping all citizens benefit public services with maximum flexibility and lower cost. Nevertheless, it should be noted that, despite many attempts, e-government services have not provided the desired pro-citizen services yet and there are a few important issues to be resolved. Thus, the growing demand, and the complexity of the public procedures on various aspects of economic, social and political life requires the advanced (modern) knowledge based on the data collection, transmission and distribution.

Regarding with the growth of data in e-government, there are many important issues to be resolved. Focusing on solving these issues, methods and approaches based on text mining technology have been proposed by some researchers. In this study, some of them are reviewed:

In [23], the system capable to process the data uploaded by citizens in the email message boards, e-mail and open discussion forums has been proposed. This system collects messages from Internet forums, classifies them, and extracts common features. To identify the trend between citizens' opinions the association rule mining technique is used in this system. These rules form the intelligent core of the system.

It should be noted that selecting the necessary sources is the key step for the implementation of any intelligent system. The sources may include the government policy database (DB), online discussion forum, blogs and social networking or social media, which have recently gained popularity and allow citizens to discuss public projects. As it includes unstructured data from various sources and in different formats (pdf, doc, docs, xml, jpg, html, etc.), it create a need for analysis system, which is capable to handle and analyze unstructured or semi-structured data to convert the documents into required format. In [24], text mining based architecture to support egovernment decisions has been proposed. This architecture is illustrated in Figure 1. In this research, in order to assist policy makers it is attempted to identify associations between policies and citizens' opinions about government decisions, through their comments written in electronic public forums, blogs and so on.

One of the priorities of e-government is the protection of citizens from damage and violence. In [25], the citizen - government relations has been investigated. In this work, it is shown that the internet platform is a cost-effective and convenient way to provide information about the crimes, strengthening the interaction between society and law enforcement agencies. 


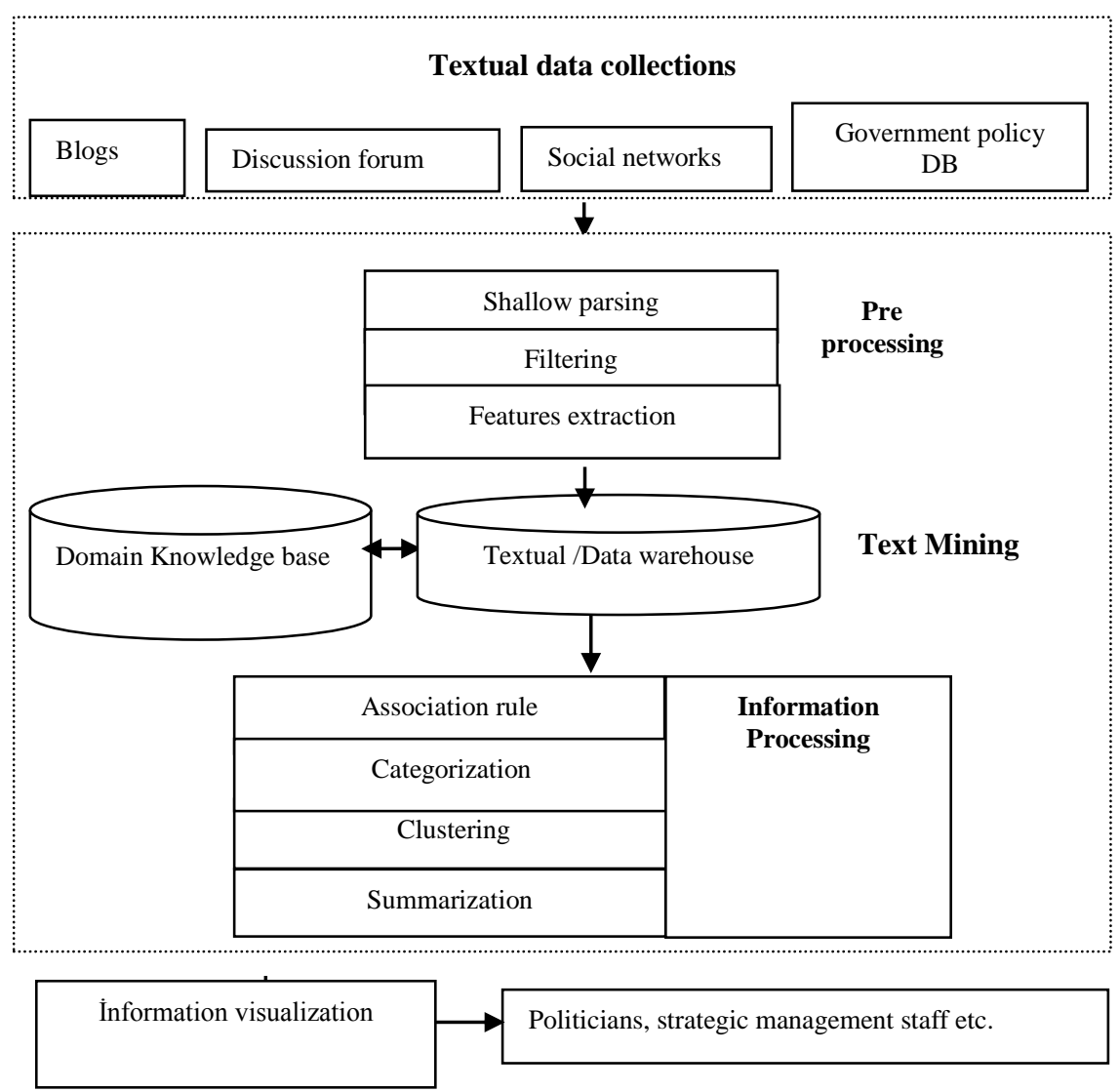

Figure1. Text-mining-based architecture for e-government decision making system [24]

Today, law enforcement agencies and non-profit organizations offer various applications to provide operative information about crimes. For example, Short Message Service (SMS), iPhone, iPad, and Android applications are used to anonymously report crime tips. In other words, citizens are allowed to submit crime tips without revealing their identity. In addition, it helps the law enforcement agencies to collect information from the citizens saving time and resources. The information about the crimes submitted online and stored in the database is written in natural language. As the volume of unstructured text grows, its analysis problems arise [26]. Thus, largescale data filtration, its comparison and differentiation require time and effort. Therefore, more efficient solutions are needed.

The efficient use of text mining technologies can help government agencies, especially law enforcement agencies for more efficient data analysis and better decision-support. In [27] has been explored the role of text analysis and classification methods in increasing the efficiency of egovernment, particularly law enforcement agencies and in providing decision-makers with information support timely. In this study, Decision Support System (DSS), which is the combination of natural language processing techniques, proximity dimensions and machine learning methods to automate and facilitate crime analysis has been proposed. In particular, information filtering about the crimes and determining whether the information about the same or similar crimes exists is of great importance. Detecting the information about the same crime is important to arrest the suspects or to improve the measures to be taken. Furthermore, identifying the similar crimes is essential for the analysis of crime's trends and gang activity and for the optimal allocation of law enforcement resources. The development of the systems, such as DSS, may save the time and resources, required for the search process and crime data analysis, and reduce the burden of analysts, so might be helpful to reduce the budget expenditures of law enforcement agencies. 
E-government portal has become one of the most important channels providing public services and citizen-government interaction. Large volume of data and rich information resources introduced by the websites of the government agencies are available in e-government system. Identifying the hot issues of public concern from this information quickly and timely is one of the main issues of e-government to make the right decisions and to achieve the goals. Hot issues of public concern can be defined using of citizens' clicks and average time on some information in egovernment environment. In [28], the method to identify hotspot information of public opinion in e-government environment has been proposed. This method analyzes the users' behavior in egovernment portal and classifies the information of public interest. Here, web log mining and fuzzy cluster analysis methods are used. The information accessed by the website users is collected through web log mining within the specified time period and the hot issues of public concern during this time period are objectively defined. And the topical issues are clustered through the fuzzy cluster analysis.

From socio-political point of view, determining the factors that motivate the users to use egovernment services is one of the key issues. Identification of the factors affecting the increase in the number of users of e-government services can provide the development of the strategies for egovernment systems that will improve the activity of government agencies. Knowledge regarding these factors and their measurement and interconnection has great importance for the development, implementation and management of successful e-government model. Decisions on acceptance or rejection of new technologies are ultimately determined by individual users. Therefore, it is important to know what factors influence the users' decision to use e-government system. This knowledge is vital for the recognition of e-government services and increasing the number of users. In [29], data mining method to determine the different demographic, cognitive and psychological factors affecting the use of e-government services by the citizens has been proposed. In this study, decision trees, neural networks, rule induction, machine learning and graphic visualization techniques are used from the computational point of view. Three artificial neural network models (multilayer neural networks, stochastic neural networks, self-organizing neural networks) and three machine learning methods (classification and regression trees, multivariate adaptive regression splines and support vector machines) are compared to standard statistical methods (Linear Discriminant Analysis). Gender, age, education, the benefit of e-government services, ease of use, compliance, trust, civic opinion and relations are accepted as the variable set. As the result of research carried out in this study, the possibility of determining the various aspects of behavior to use e-government services and the classification opportunities of data mining methods have been identified through the discovery of the database complex samples.

A number of sites (portals) are available in e-government. Users can benefit from these sites (portals) to get important information and to request a number of services. The availability of the blogs, where the citizens can easily and conveniently express their opinions and experiences regarding public services, is very important for the government. Thus, taking into account the citizens' opinions can lead to the development of a democratic government and the improvement of the quality of services. In [30], a prototype system using text mining and data mining techniques has been proposed. This system classifies the citizens' opinions by six service categories. These service categories include education, agriculture, healthcare, transport, IT and industry. First, the citizens' opinions in e-government portal are gathered. Subsequently, the comments are initially processed for further analysis. Pre-processing is one of the data mining processes that removes unnecessary or invalid data from the text processes. Afterwards, the key words dictionary is created for the classification. The dictionary of common words to remove unnecessary words, the dictionary of key words to classify the opinions by six categories, and the dictionary of positive and negative words to classify the opinions by praise, criticism and neutral for the decision-making have been created.

One of the important aspects of e-government is to give citizens the opportunity to 
participate in the decision making process. In [31], text and data mining techniques are used for the collection and analysis of citizen opinions about government decisions. The two-level analysis is used here. The first part of an approach identifies and extracts the expressions from the comments of the users to define their position. The second part analyzes the extracted expressions in order to determine a positive or negative attitude toward a certain issue. HTML parsing is used to process the data. The information block is divided into small parts through HTML parsing, which helps to eliminate non-text elements. Non-text elements may include images, videos, scripts, text graphics tools and so on. Then, tokenization is applied to extract the lexical elements from the users' texts. Afterwards, decision tree classification module is used.

All of these studies show that text mining technology currently plays an important role for data mining in e-government, and the methods based on this technology need to be improved.

\section{Social network technologies in e-government analysis}

Over the past decade, a new stage in the study of social network analysis has begun. Thus, we mainly focus on the social network analysis, which has thousands or millions of small nodes. There are two reasons for this: 1) the mass use and expansion of social media networks; 2) the availability of big dataset coming from this media. Although the interest in social networks has increased, the introduction of this methodology in e-government hasn't been paid attention. Let's review some studies in this field.

In [32], a new approach based on the social networking analysis for the e-government evaluation has been proposed. The approach mainly focuses on the documents flow network between various government agencies, citizens and businesses. The networks are created in 4 stages in this work:

1. Identifying the services provided by the central registry: the analysis of the data provided in websites and regulations is used for this.

2. Forming each service delivery protocols: a combination of analysis of the decision makers' opinions, who are involved in the delivery and services specified in regulations, is used for this.

3. Two networks are set up for each service mentioned above: showing the situation before and after the reform.

4. Connecting the separate service networks in accordance with the previous and later situations.

3 actors are distinguished in this network: a citizen - as an initiator of the service delivery process, the public administration institutions prosecuting these services, and other organizations. All the links in the network indicate the document flow, while the number links shows the number of documents exchanged between the relevant actors. Pajek software is used here for the network development and visualization.

E-government sites are regularly measured through various metrics by consulting companies, international organizations and researchers. In [33] a new method for the evaluation of e-government has been proposed. The main purpose of this study is to improve the estimates using web metrics and social network analysis techniques. The proposed method has been reviewed as a pilot in the government sites of Canada, USA, UK, New Zealand and Czech. The average distance between the actors, the distribution of the paths lengths, input and output rates are used here. The network contains a set of actors and a set of aimed edges uniting the actors in pairs. The actors consist of the documents received from the Internet, and the links - the hyperlinks, which can be used for the documents' navigation. Access rate of each actor indicates the number of input edges to the actor; the output rate shows actors from the edge. The sum of the input and output rates shows the rate of the actor. These estimates are used to identify the navigability and nodality of the site. The implemented analysis shows that the US and Canadian 
sites provide better navigation than those of the Great Britain, whereas, the British site more powerful centers on the Web.

In [34], the social and information network analysis methods to achieve a better and efficient analysis of e-government have been used. In this study, the presence of the government on the Web and the interaction of various government departments are analyzed. Furthermore, the relationship between the government and non-governmental organizations are also investigated. The main purpose of this study is to implement the efficient research on e-government hyperlinks through the social network analysis methods. Hyperlink network is built in the following way: first, a database of links between different Web organizations is created. The acquired data is stored and presented in a graphical form. The nodes indicate the web pages, while the directed edges show the hyperlink. All these nodes and a set of directed edges are presented as a web graph. This directed graph may not be strongly related: there can be a pair of pages that it may be impossible to go from one to another via hyperlinks. Here, the hyperlinks within the page are referred as internal links, and the links outside the page - as external links. Then, the way the developed network is linking inside and outside of e-government is studied. VOSON system is used to build a hyperlink network [35]. This system is network software used for the collection and analysis of hyperlinks network. After the network created NodeXL software is used to explore the network graphs. NodeXL is a free open system [36]. Four basic nodality metrics are applied for the network analysis, which are nodality by rate, nodality by proximity, nodality by mediation and PageRank. Nodality by rate is used to find the most "popular" subject (i.e., which subject is connected to the nodes most in the network). Nodality by mediation is used to find the website in the network, which has more powerful impact. To find the shortest distance between the nodes nodality by proximity is used. PageRank is used to find the most significant actor. At the end, as a result of the network analysis, the most popular, powerful, important and central entity is identified.

The growing use of the Internet and the development of technology have an impact on the notion of nodality - one of the primary tools of government policy, i.e., the public authority in the center of the social and information networks [37, 38]. In [39], social network analysis methods are used for the quality analysis of the government's nodality on the Web. Here, nodality, visibility and navigability concepts are principally discussed. Later on, the two main metrics - structural and user metrics are applied to the web sites of the relevant ministries of foreign affairs of three countries (US, GB and Australia). Structural metrics is used for the calculation of the average distance between two random pages and for the interaction of the sites. Social network analysis metrics is used to comparatively assess the navigation of each site. This study mainly focuses on search operations rather than the service operations. The obtained results are used for the evaluation of the website on five areas: visibility, accessibility, extraversion, navigation and competitiveness.

Here, the visibility is calculated through the internal link analysis, while extraversion through the external link analysis. The percentage of internal links that goes beyond the home page on the site is a measure of the information accessibility. Navigation is calculated through web metrics and user experiments.

In [40], the relations of the government agencies with the audience via Facebook and the citizens' comments on their posts are explored. Facebook facilitates the conversation between the individuals in the form of specific social groups within the formal accounts. This study is based on the horizontal position of the network, network density and the number of messages between the network members. 4280 posts written by the public authorities have been analyzed to trial these trilateral relations. The results show that: 1) the horizontal nature of the network has a positive impact on the participation, which is accompanied by a high number of users; 2) the comments written by the users in the Web 2.0-based environment is more important than the messages broadcasted by the organizations; 3 ) increase in the number of posts shares by the organizations has a negative impact on the number of comments written by the users. 
In [41], a hybrid approach (social network analysis methods and triple helix of indicators) to set the certain aspects of e-government is proposed. In this research, the network is built and analyzed based on the articles written on the e-government by the co-authors from various institutes, countries and regions. Social network analysis methods, including nodality at a rate, density and cluster are used to determine hidden network structures and properties of egovernment network. The clusters are defined through spring-embedding algorithm on NetDraw software packages. The links here equal to the number of articles written by the co-authors by institutions, countries and regions. Network features are calculated via NetMiner 3.3.0. Helix indicators are used to check bilateral and trilateral relations.

Apparently, the study of social network analysis in the field of e-government has great potential, but this area has not adequately been explored. In future studies, we will touch upon a number of issues on the application of social network analysis in e-government.

\section{Requirement to e-government and approaches for its development}

One of the objectives of e-government is to improve the quality of services provided to citizens. Therefore, the requirements of e-government should mainly come forward to the needs of citizens. E-government can be considered a new type of state IT system. In general, requirements imply not only the facts, but also acquired information and knowledge. The basic requirements related to e-government are as follows [42]:

$\checkmark$ citizens to be involved in the management;

$\checkmark$ basic plan to be consistent with the national IT plan;

$\checkmark$ problems and requirements to be aligned with each other;

$\checkmark$ aim, competitiveness, short-term and long-term assessment set forth to be specified;

$\checkmark$ IT assessment strategy to be developed;

$\checkmark$ basic IT plan to be continuously monitored.

The general e-government requirements cover the exchange and quality of information and knowledge system. However, considering the number of skilled IT personnel and government agencies, we can see that a lack of human resources still remains. The concept of outsourcing is applied to reduce such problems. It should be noted that the developed countries and the developing countries may have different approaches to the development of e-government. In the developed countries, each government agency has completed its IT projects and computer data center. Thus, parts of e-government in these countries are available in many state-owned enterprises. When we look through each part of e-government, we can see that information and knowledge systems are operating effectively. The main problem here is the combination of these systems. Taking into account e-government approach, it can be achieved by combining all available information and knowledge systems. This approach is known as a distributed model. Figure 2 presents electronic data exchange (EDE) model, which provides the integration of various data standards between different government agencies [42]. 


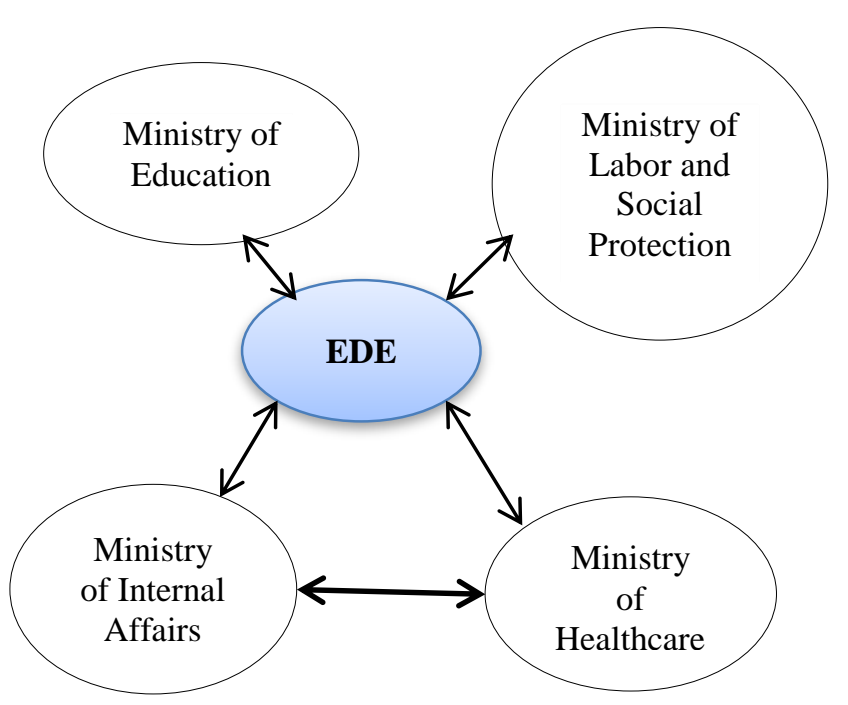

Figure2. Distributed Model

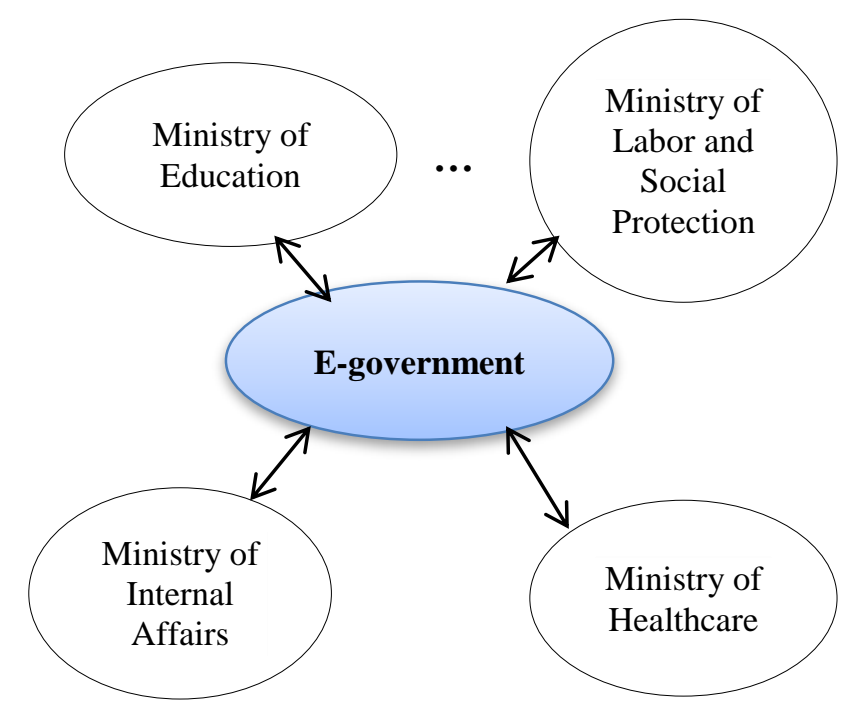

Figure3. Centralized Model

As mentioned above, e-government in the developing countries differ from the developed countries, since in these countries, information and knowledge systems, information technology and infrastructure is underdeveloped. Therefore, common standards of computer and information technologies must be resolved at the initial stage of the e-government project. The main duty of the government is to identify the e-government concept of all government agencies, its mission, goals, objectives, strategies and tactics and to ensure the same e-government view of each authority. As a result of central planning, a comprehensible view can be achieved during the implementation of e-government projects. Consequently, each authority will be able to interchange with own resources through a "single window" principle. It is intended for the countries with insufficient resources and called centralized model (Figure 3). This model is suitable for a number of developing countries. At present, distributed model are applied in some areas and in future it is planned to completely shift to the distributed model.

\section{Conclusion}

E-government initiatives aimed at increasing the efficiency of the state performance, improving the public services to citizens and business sector, developing the efficiency of the internal government performance, as well as expanding the participation of citizens in decision making process. Nevertheless, many studies have shown that a large part of initiatives to implement the e-government projects is still pending all over the world. Summing up the above mentioned, we see that there is a need for research on the following issues in e-government:

$\checkmark$ citizens' involvement in e-participation;

$\checkmark$ increasing citizens' satisfaction;

$\checkmark$ defining the factors affecting the increased use of e-government portal;

$\checkmark$ identifying the key interests of the citizens;

$\checkmark$ improving the tools to analyze the citizens' views and opinions;

$\checkmark$ improving the tools for the exponentially growing data analysis;

$\checkmark$ developing the methods of detection and analysis of hidden social networks in e-government;

$\checkmark$ ensuring security of citizens in e-government portal;

$\checkmark$ introducing new technologies;

$\checkmark$ personal data protection issues;

$\checkmark$ digital divide;

$\checkmark$ open government, e-government 2.0 


\section{References}

1. Bekkers V. J. J. M., Zouridis S. Electronic service delivery in public administration: some trends and issues //International Review of Administrative Sciences, 1999, vol.65, no.2, pp.183-196.

2. Carter L., Bélanger F. The Utilization of E-Government Services: Citizen Trust, Innovation and Acceptance Factors // Information Systems Journal, 2005, vol.15, no.1, pp.5-25.

3. Patel H., Jacobson D. Factors Influencing Citizen Adoption of E-Government: A Review and Critical Assessment / 16th European Conference on Information Systems, Galway, 2008, pp.176-188.

4. Schelin S. H. E-Government: An overview. Public Information Technology: Policy and Management Issues, 2003, pp.120-137.

5. Baum C., Di Maio A. Gartner's four phases of e-government model. Gartner Group, 2000.

6. Deloitte Consulting, Deloitte \& Touche. At the dawn of e-government: The citizen as customer. New York: Deloitte Research, 2000.

7. Layne K., Lee J. Developing fully functional e-government: A four stage model // Government Information Quarterly, 2001, vol.18, no.2, pp.122-136.

8. Hiller J. S., Belanger F. Privacy strategies for electronic government. E-Government 2001, Rowman \& Littlefiels publisher, pp.162-198.

9. Wescott C. G. E-Government in the Asia-pacific region // Asian Journal of Political Science, 2001, vol.9, no.2, pp.1-24.

10. United Nations \& American Society for Public Administration (ASPA). Benchmarking egovernment: A global perspective. New York: U.N. Publications, 2002.

11. Moon M. J. The Evolution of E-Government among Municipalities: Rhetoric or Reality? // Public Administration Review, 2002, vol.62, no.4, pp.424-433.

12. Chandler S., Emanuels S. Transformation not automation / In Proceedings of 2nd European Conference on E-government, 2002, pp. 91-102.

13. Windley P. J. eGovernment maturity. USA: Windleys' Technolometria, 2002. www.windley.com/docs/eGovernment\%20Maturity.pdf

14. Toasaki Y. E-Government from A User's Perspective. APEC telecommunication and information working group, Chinese Taipei, 2003.

15. Rohleder S. J., Jupp V. E-government Leadership: Engaging the customer. Accenture, 2003.

16. Siau K., Long Y. Synthesizing e-government stage models-a meta-synthesis based on metaethnography approach // Industrial Management \& Data Systems, 2005, vol.105, no.4, pp.443-458.

17. Shahkooh K. A., Saghafi F., Abdollahi A. A proposed model for e-Government maturity /3rd International Conference on Information \& Communication Technologies: from Theory to Applications, 2008, pp.1-5.

18. Almazan R. S., Gil-Garcia J. R. E-Government Portals in Mexico // Electronic Government: Concepts, Methodologies, Tools and Applications, 2008, pp.367-376.

19. Kim D.-Y., Grant G.E-government maturity model using the capability maturity model integration // Journal of Systems and Information Technology, 2010, vol.12, no.3, pp.230-244.

20. Alhomod S. M., Shafi M. M., Kousarrizi M. N., Seiti F., Teshnehlab M., Susanto H., Batawi Y. A. Best Practices in E government: A review of Some Innovative Models Proposed in Different Countries // International Journal of Electrical \& Computer Sciences, 2012, vol.12, no.1, pp.1-6.

21. United-Nations. UN E-Government Survey 2012: E-Government for the People, 2012.

22. Lee G., Kwak Y. H. An Open Government Maturity Model for social media-based public engagement // Government Information Quarterly, 2012, vol.29, no.4, pp.492-503.

23. Cardeñosa J., Gallardo C., Moreno J.M. Text Mining Techniques to Support e-Democracy Systems / In: CSREA EE 2009, pp.401-405. 
24. Rao G. K., Dey S. Text Mining Based Decision Support System (TMbDSS) for E-governance: A Roadmap for India // Advances in Computing and Information Technology, 2011, vol.198, pp.270-281.

25. Linders D. From e-government to we-government: Defining a typology for citizen coproduction in the age of social media // Government Information Quarterly, 2012, vol.29, no.4, pp.446-454.

26. Song W., Kim J. Y., Schulzrinne H., Boni P., Armstrong M. Using IM and SMS for emergency text communications / Proceedings of the 3rd International Conference on Principles, Systems and Applications of IP Telecommunications, 2009, pp.1-4.

27. $\mathrm{Ku} \mathrm{Ch.-H.,} \mathrm{Leroy} \mathrm{G.} \mathrm{A} \mathrm{decision} \mathrm{support} \mathrm{system:} \mathrm{Automated} \mathrm{crime} \mathrm{report} \mathrm{analysis} \mathrm{and}$ classification for e-government // Government Information Quarterly, 2014, vol.31, no.4, pp.534-544.

28. Wang S., Zhang J., Yang F., Ye J. Research on Cluster Analysis Method of E-government Public Hotspot Information Based on Web Log Analysis // Computing and Information Technology, 2013, vol.22, pp.11-19.

29. Mostafa M. M., El-Masry A. A. Citizens as consumers: Profiling e-government services' users in Egypt via data mining techniques // International Journal of Information Management, 2013, vol.33, no.4, pp.627-641.

30. Tilahun T., Sharma D.P. Design and Development of E-Governance Model for Service Quality Enhancement // Journal of Data Analysis and Information Processing, 2015, vol.3, no.3, pp.55-62.

31. Stylios G., Christodoulakis D., Besharat J., Vonitsanou M.-A., Kotrotsos I., Koumpouri A., Stamou S. Public Opinion Mining for Governmental Decisions // Electronic Journal of eGovernment, 2010, vol.8, no.2, pp.203-214.

32. Jovanovska M. B., Erman N., Todorovski L. Evaluating the Maturity Level of e-Government Back-Office with Social Network Analysis / 20th NISPAcee Annual Conference. Public Administration East and West: Twenty Years of Development. Ohrid, Macedonia, 2012.

33. Petricek V., Escher T., Cox I. J., Margetts H. The Web Structure of E-Government Developing a Methodology for Quantitative Evaluation / International World Wide Web Conference Committee, 2006, pp.669-678.

34. Kadriu A., Saveska M., Abazi-Bexheti L. E-Government Exploration using Social Network Analysis Methods // International Journal of Humanities and Management Sciences, 2013, vol.1, no.2, pp.151-154.

35. www.uberlink.com/

36. http://nodexl.codeplex.com/

37. Hood C. The Tools of Government (London: Macmillan), 1983.

38. Hood C., Margetts H. The Tools of Government in the Digital Age (London: Palgrave), 2006.

39. Escher T., Margetts H., Petricek V., CoxI. Governing from the Centre? Comparing the Nodality of Digital Governments // Prepared for delivery at the 2006 Annual Meeting of the American Political Science.

40. Halpern D., Katz J. E. From e-government to Social Network Government: Towards a Transition Model / Proceedings of the 4th Annual ACM Web Science Conference, 2012, pp.119-127.

41. Khan G. F., Park H. W. The e-government research domain: A triple helix network analysis of collaboration at the regional, country, and institutional levels // Government Information Quarterly, 2013, vol.30, no.2, pp.182-193.

42. Chutimaskul W. e-Government Analysis and Modeling / 3rd International Workshop on "Knowledge Management in e-Government", 2002, vol.7, pp.112-123. 